\title{
Stability of autoantibodies and their relation to genetic and metabolic markers of Type I diabetes in initially unaffected schoolchildren
}

\author{
P. Kulmala ${ }^{1}$, J. Rahko ${ }^{1}$, K.Savola ${ }^{1}$, P. Vähäsalo ${ }^{1}$, R. Veijola ${ }^{1}$, M.Sjöroos ${ }^{2}$, A. Reunanen ${ }^{3}$, J.Ilonen ${ }^{2}$, M. Knip ${ }^{4}$ \\ ${ }^{1}$ Department of Paediatrics, University of Oulu, Finland \\ ${ }^{2}$ Turku Immunology Centre and Department of Virology, University of Turku, Finland \\ ${ }^{3}$ The National Public Health Institute, Helsinki, Finland \\ ${ }^{4}$ Medical School, University of Tampere and Department of Paediatrics Tampere University Hospital, Finland
}

\section{Abstract}

Aims/hypothesis. To study temporal changes in positivity for autoantibodies associated with Type I (insulin-dependent) diabetes mellitus and the relations between these antibodies, $H L A-D Q B 1$-risk markers and first-phase insulin response (FPIR) in non-diabetic schoolchildren.

Methods. The stability of the antibody status over 2 years was assessed in 104 schoolchildren initially positive for islet cell antibodies (ICA) or antibodies to the $65000 \mathrm{M}_{\mathrm{r}}$ isoform of the glutamic acid decarboxylase (GADA) or both and in 104 antibody-negative control children matched for sex, age and place of residence. All children were also studied for their first-phase insulin response and $H L A-D Q B 1$ alleles on the second occasion.

Results. On the second occasion 3 of the 98 initially ICA-positive children, $3 / 13$ of those positive for antibodies to the IA-2 protein (IA-2A), 1/17 GADA-positive and $2 / 7$ of those positive for insulin autoantibodies (IAA) tested negative for these antibodies. Children with IA-2A, GADA, IAA and multiple $(\geq 2)$ antibodies had significantly lower first-phase insulin responses than the control children. In contrast, these responses did not differ between subjects with and without specific $H L A-D Q B 1$-risk alleles or genotypes. Of the six subjects with a considerably reduced first-phase insulin response three had multiple antibodies on both occasions but none of them had a $D Q B 1$ genotype conferring increased diabetes risk. Two subjects progressed to Type I diabetes within 3.4 years of follow-up, both of them having multiple antibodies and a considerably reduced first-phase insulin response but neither of them having a $D Q B 1$ risk genotype.

Conclusions/interpretation. Positivity for diabetes-associated autoantibodies is a relatively stable phenomenon in unaffected schoolchildren, although conversion to seronegativity can occur occasionally. Our observations also indicate that $D Q B 1$ alleles associated with decreased susceptibility to Type I diabetes do not protect from impaired beta-cell function or from progression to overt disease in initially unaffected schoolchildren. [Diabetologia (2000) 43: 457-464]

Keywords Autoantibodies, FPIR, HLA, schoolchildren, Type I diabetes.
Received: 29 September 1999 and in revised form: 10 January 2000

Corresponding author: P. Kulmala, MD, Department of Paediatrics, University of Oulu, Kajaanintie 50, FIN-90220 Oulu, Finland

Abbreviations: CI, 95\% Confidence interval for difference; FPIR, first-phase insulin response to intravenous glucose; GADA, antibodies to the $65000 \mathrm{M}_{\mathrm{r}}$ isoform of the glutamic acid decarboxylase; IA-2A, antibodies to the IA-2 protein; IAA, insulin autoantibodies; ICA, islet cell antibodies; JDF, Juvenile Diabetes Foundation; RU, relative units; IVGTT, intravenous glucose tolerance test; IQR, interquartile range.
Despite extensive research over several decades the pathomechanism(s) underlying Type I (insulin-dependent) diabetes mellitus have remained poorly defined. Also, the course of the destructive process in the pancreatic beta cells during the prodromal period is inadequately characterised. Animal models and studies on first-degree relatives of subjects with Type I diabetes have accumulated data on genetic, autoimmune and metabolic factors contributing to the disease process. Only about $10 \%$ of the new patients have, however, a first-degree relative with Type I dia- 
betes [1,2], and therefore studies on healthy subjects representing the general population could provide essential information.

The course of the preclinical phase of the disease and the identification of potential predictive and preventive strategies in the general population are the current focus of research on Type I diabetes. Autoantibodies to various beta-cell antigens have proved to be an early marker of ongoing beta-cell destruction and are widely used to assess the risk of future manifestation of clinical disease in first-degree relatives of patients with Type I diabetes [3]. Similarly, a reduced early insulin response to intravenous glucose, reflecting impaired beta-cell function, is highly predictive for rapid progression to overt diabetes [4].

We studied the stability of the autoantibody status over 2 years in 104 initially antibody-positive healthy schoolchildren and 104 antibody-negative control children matched for sex, age and place of residence. We also assessed the relations between disease-associated autoantibodies, genetic $H L A-D Q B 1$-risk markers and first-phase insulin response (FPIR). All subjects were monitored for progression to Type I diabetes over 3.4 years.

\section{Subjects and methods}

Subject and study design. A series of 104 antibody-positive healthy schoolchildren and 104 control children (matched for age, sex and place of residence) were recruited from the study on beta-cell autoimmunity in schoolchildren in northern Finland. The study was initiated at the beginning of 1994, when all 7 to 16-year-old schoolchildren $(n=4280)$ living in five municipalities in the Province of Oulu (Haapajärvi, Ii, Oulainen, Yli-Ii and Ylikiiminki) were invited to take part in the study. Informed consent was obtained from the subjects or their parents or both. The study design was approved by the ethics committee, Faculty of Medicine, University of Oulu. Of the subjects $17(0.4 \%)$ had clinical Type I diabetes at the time of recruitment for the study. Information on the HLA genotype was available in 15 of these children, out of whom $6(40 \%)$ were DQB1*02/0302 heterozygous, $4(27 \%)$ carried the DQB1*0302/x genotype (x other than $* 02, * 0301$ or *0602) and $3(20 \%)$ the DQB $1 * 02 / y$ genotype (y other than $* 0302$, *0301 or *0602). One had the DQB1*0302/0602 genotype and one the DQB1*02/0301 genotype.

Serum samples were initially collected from 3662 subjects who gave their consent to take part in the study. Of these 10 were excluded as they already had previously diagnosed clinical diabetes. Altogether, 3652 non-diabetic schoolchildren $(85.3 \%)$ were included and all of them were initially analysed for islet cell antibodies (ICA) and for antibodies to the 65000 $\mathrm{M}_{\mathrm{r}}$ isoform of glutamic acid decarboxylase (GADA). More recently all subjects were in addition tested for insulin autoantibodies (IAA) and antibodies to the protein tyrosine phosphatase-related IA-2 molecule (IA-2A). There were 106 subjects $(2.9 \%)$ who initially tested positive for ICA or GADA or both. Of these 104 and a further 104 control children negative for all four antibody specificities and matched for age, sex and place of residence, were invited to take part in the second part of the study. Two of the subjects who were initially positive for ICA or GADA or both were excluded because they progressed to Type I diabetes before the second part of the study. The second part of the study included blood sampling for autoantibody determinations (ICA, IA-2A, GADA and IAA), interview/questionnaire, physical examination and an intravenous glucose tolerance test (IVGTT). The group of autoantibody-positive children comprised 51 boys and 53 girls and their mean age at the time of the IVGTT was 13.7 years (range 9.4-18.8 years). Of the antibody positive subjects two had a first-degree relative with Type I diabetes (the father of one subject and the mother of the other subject). The subjects were asked whether and when they had had upper respiratory tract infections, gastroenteritis or other specific infections since the initial blood sampling and whether they had had symptoms associated with diabetes (thirst, excessive drinking, weight loss, tiredness). Physical examination included measurement of weight, height and waist:hip ratio. Relative weight (actual weight in relation to mean weight for height) was assessed based on Finnish growth charts [5].

The children were observed for progression to Type I diabetes from the time of the second sampling to the end of May 1999 for a mean of 3.4 years (range 3.2-3.6 years) using the Central Drug Registry of the Social Insurance Institute, which has an ascertainment rate of more than $99 \%$ for new patients with Type I diabetes (Reunanen A, personal communication).

Intravenous glucose tolerance tests. We successfully carried out IVGTTs in 103 antibody-positive (99\%) and 103 antibodynegative subjects (99\%) according to the ICARUS protocol [6]. After $10-16 \mathrm{~h}$ of fasting, $0.5 \mathrm{~g} / \mathrm{kg}$ glucose in a $20 \%$ solution was infused intravenously for $3 \mathrm{~min} \pm 15 \mathrm{~s}$. Blood samples were taken 5 and 0 min before the infusion and 1, 3, 5 and 10 min after the infusion had been completed. Serum insulin concentrations were measured with an enzyme-linked immunosorbent assay [7]. The sensitivity of the assay was $0.5 \mathrm{mU} / \mathrm{l}$ and the intra-assay and inter-assay coefficients of variation were less than $7.5 \%$ and $9.3 \%$, respectively. Blood glucose concentrations were analysed with the glucose oxidase method [8]. The first-phase insulin response (FPIR) to glucose was defined as the sum of the 1-min and 3-min serum insulin concentrations.

Islet cell antibodies. We measured ICA by a standard immunofluorescence method using sections of frozen human group $\mathrm{O}$ pancreas [9]. All sera with detectable ICA were titrated to end-point dilution and the results were expressed in Juvenile Diabetes Foundation (JDF) units by comparison with an international standard reference serum [10]. The detection limit for ICA was 2.5 JDF units. Our laboratory had a sensitivity of $100 \%$, a specificity of $98 \%$, a validity of $98 \%$ and a consistency of $98 \%$ in the fourth round of the international workshops on standardization of the ICA assay [11].

Antibodies to the IA-2 molecule. We analysed IA-2A with a radiobinding assay as described previously [11]. Briefly, the intracellular fragment of the IA-2 protein, including amino acids 605-979, was produced by in vitro transcription and translation in the presence of ${ }^{35} \mathrm{~S}$-methionine. Serum samples were incubated overnight with labelled IA-2 protein (10 $000 \mathrm{cpm} /$ well). Immunocomplexes were isolated using protein A sepharose (Pharmacia Biotech, Uppsala, Sweden). All the samples were tested in duplicate. The radioactivity was measured in a scintillation counter and the results are expressed in relative units (RU) based on a standard curve run on each plate. The cutoff limit for positivity $(0.43 \mathrm{RU})$ was set at the 99 th centile for 


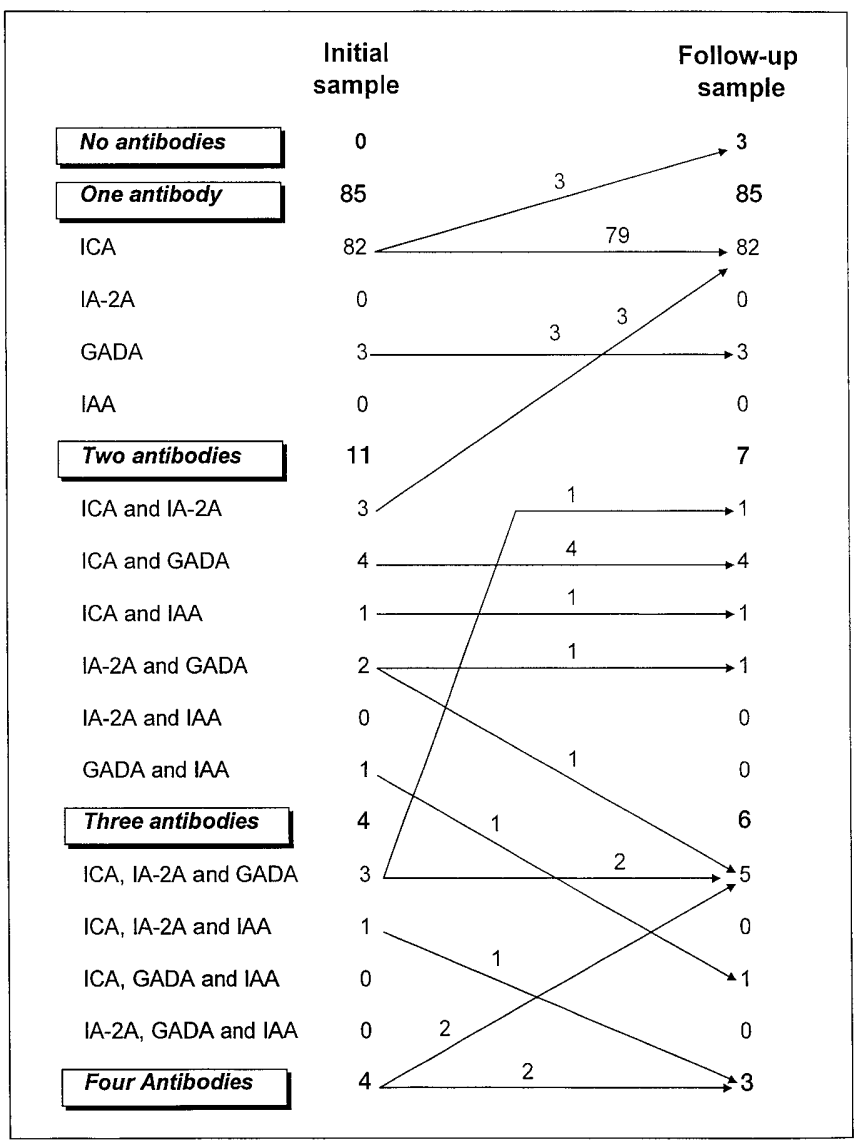

Fig. 1. Distribution of ICA, IA-2A, GADA and IAA in the initial and follow-up samples of 104 non-diabetic Finnish schoolchildren initially tested for ICA and GADA. Numbers of subjects are presented and the arrows indicate change from one group to another between the initial and follow-up samples

374 non-diabetic Finnish children and adolescents. The disease sensitivity of our assay was $62 \%$ and the disease specificity $97 \%$ based on 140 samples included in the Multiple Autoantibody Workshop [12].

Antibodies to glutamic acid decarboxylase. We quantified GADA with a radiobinding assay as described previously [13]. Briefly, serum samples were incubated overnight with ${ }^{35} \mathrm{~S}$-methionine-labelled in vitro transcribed and translated human recombinant $\mathrm{GAD}_{65}$ protein. All the samples were analysed in quadruplicate with and without an excess of unlabelled $\mathrm{GAD}_{65}$. Immunocomplexes were isolated using protein A sepharose (Pharmacia Biotech). The radioactivity was measured in a scintillation counter and the results are expressed in relative units (RU) representing the specific binding as a percentage of that obtained with a positive standard serum. The cut-off limit for GADA positivity was defined as 6.6 relative units (RU), representing the 99th centile in a series of 372 healthy control children. The disease sensitivity of this assay was $79 \%$ and the disease specificity $97 \%$, based on the Multiple Autoantibody Workshop [12].

Insulin autoantibodies. We analysed IAA with a radiobinding micro-assay, modified from that described previously [14]. The serum samples $(5 \mu l)$ were incubated on 96-deep-well plates with mono ${ }^{125} \mathrm{I}$-(TyrA14)-labelled human insulin. After incubation for $72 \mathrm{~h}$, the immunocomplexes were precipitated using protein A sepharose. The volume of the incubation reaction was doubled by adding the reaction buffer [TBT; $50 \mathrm{mmol} / \mathrm{l}$ TRIS, pH 8.0, $1 \%$ (v/v) Tween 20]. After washings with reaction buffer, the samples were transferred to microtitration plates, scintillation liquid was added and the bound activity was measured with a liquid scintillation counter (1450 MicroBeta Trilux; EG\&G Wallac, Turku, Finland). If the total binding exceeded the 95th centile in 371 non-diabetic Finnish subjects, the sample was reanalysed in the presence or absence of unlabelled insulin and the specific binding was expressed in relative units (RU) based on a standard curve run on each plate using the MultiCalc software program (EG\&G Wallac). The standard curve was constructed from nine serial dilutions of a serum from a patient with a high insulin antibody titre and a serum from an IAA-negative subject. The cut-off limit for IAA positivity was set at the 99 th centile in the 371 non-diabetic subjects (1.56 RU). The performance characteristics of this assay were compared to that run in Bristol [14] based on a blinded sample exchange comprising 100 samples. There was a strong correlation between the two assays $(r=0.96$; $p<0.001)$ and the concordance rate was $94 \%$. The disease sensitivity of our micro-assay was $35 \%$ and the specificity $100 \%$ based on 140 samples derived from the 1995 Multiple Autoantibody Workshop [12].

Typing of $H L A$. We defined $H L A-D Q B 1$ alleles by a previously described method based on time-resolved fluorescence [15]. We used four sequence-specific oligonucleotide probes to identify the following $D Q B 1$ alleles known to be associated with either susceptibility to or protection against Type I diabetes in the Finnish population: DQB1*0302, DQB1*02, DQB1*0602 or 0603, and DQB1*0301 [16]. To differentiate between DQA $1 * 05-\mathrm{DQB} 1 * 02$ (DR3) and DQA $1 * 0201$ DQB1*02 (DR7) haplotypes all DQB1*02-positive samples were further analysed for the presence of the DQA $1 * 05$ or the DQA $1 * 0201$ allele [17].

Statistical analyses. Student's $t$ test was used to analyse normally distributed continuous variables and the Mann-Whitney U test and Kruskall-Wallis analysis in skewed distributions. Differences in the distribution of subjects between groups were tested with chi-squared statistics with Yates' correction unless any expected value was less than five, when Fisher's exact test was used [18]. Correlations between variables were tested with Spearman's non-parametric correlation analysis $\left(r_{s}\right)$. A two-tailed $p$ value of 0.05 or less was considered to indicate statistical significance. All the statistical analyses were done using the SPSS statistical software package for Windows, version 8.0 (SPSS, 1998, Chicago, Ill., USA).

\section{Results}

The stability of the antibody status. The distribution of the specific antibody combinations in initial and follow-up samples of 104 subjects initially positive for ICA and/or GADA is shown in Figure 1. The mean time interval between the first and second serum samples was 1.9 years (range 1.7-2.2 years). Only 3 out of the $98(3.1 \%)$ subjects initially positive for ICA tested negative in the follow-up sample. All of them had low levels of ICA (4, 6 and 6 JDF units) in 
Table 1. Characteristics of the initially antibody-positive children and the antibody-negative control children

\begin{tabular}{|c|c|c|c|c|c|}
\hline $\begin{array}{l}\text { Antibody positivity in the } \\
\text { initial blood sample }\end{array}$ & $n$ & Sex, $M / F$ & $\begin{array}{l}\text { Age at the } 1^{\text {st }} \text { sample, } \\
\text { years }\end{array}$ & Relative weight, $\%$ & Waist : Hip ratic \\
\hline Controls & 104 & $51 / 53$ & $11.8(7.5-16.3)$ & $104(78-147)$ & $0.82(0.68-1.61)$ \\
\hline Antibody-positive & 104 & $51 / 53$ & $11.8(7.5-17.0)$ & $103(78-150)$ & $0.83(0.70-1.60)$ \\
\hline IA-2A-positive & 13 & $9 / 4$ & $10.2(7.8-13.4)^{\mathrm{a}}$ & $110(78-150)$ & $0.86(0.71-1.03)$ \\
\hline GADA-positive & 17 & $10 / 7$ & $11.2(7.9-15.0)$ & $105(85-150)$ & $0.84(0.73-1.03)$ \\
\hline IAA-positive & 7 & $6 / 1$ & $11.2(9.0-15.3)$ & $104(85-116)$ & $0.85(0.77-0.94)$ \\
\hline
\end{tabular}

Data are number of subjects, mean (range) for age and median (range) for other continuous variables. The comparisons were done between the group of control children and each of the other groups. ${ }^{\mathrm{a}} p=0.012{ }^{\mathrm{b}} p=0.019$, all other $p$ values were non-significant

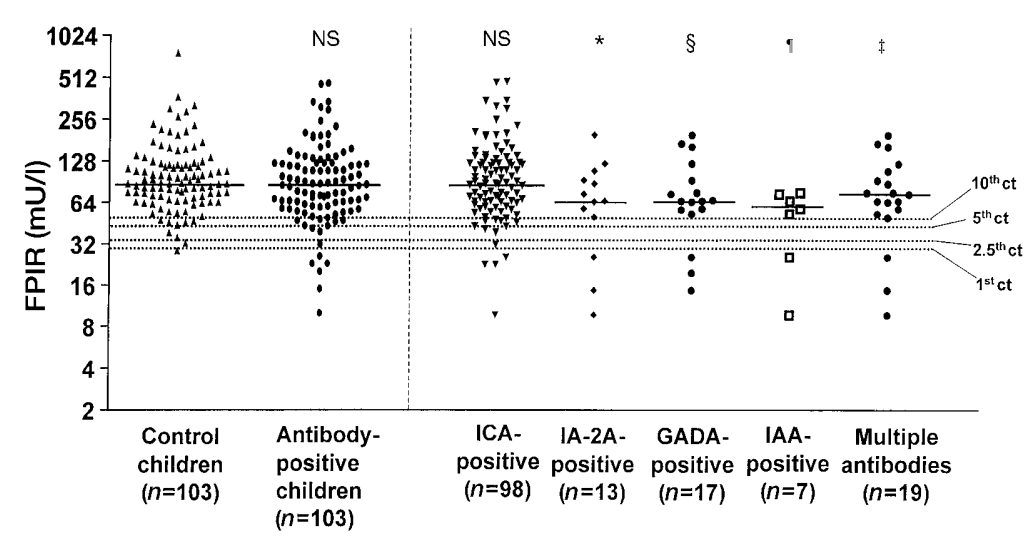

Fig. 2. First-phase insulin response (FPIR) to intravenous glucose in autoantibody-positive and autoantibody-negative healthy Finnish schoolchildren. FPIR values are shown in a Log 2 scale. The solid lines indicate median values of FPIR and the dotted lines indicate the $1 \mathrm{st}(29.5 \mathrm{mU} / \mathrm{l}), 2.5$ th $(35.0 \mathrm{mU} / \mathrm{l})$, 5 th $(45.0 \mathrm{mU} / \mathrm{l})$ and 10 th $(52.1 \mathrm{mU} / \mathrm{l})$ centiles of the FPIR values in the control group. ${ }^{*} p=0.033,{ }^{\S} p=0.027,{ }^{\pi} p=0.010$ and ${ }^{\ddagger} p=0.048$, when compared with the control children. $\mathrm{ct}=$ centile

the first sample, and they were negative for the other autoantibodies on both occasions. Correspondingly, $3 / 13(23.1 \%)$ subjects initially positive for IA-2A turned negative for IA-2A and low initial levels of these antibodies also characterised them. They tested negative for GADA and IAA on both occasions but were positive for ICA with increasing levels over time. Only $1 / 17$ (5.9\%) subjects initially positive for GADA turned negative for GADA in the follow-up sample. This boy had relatively high levels of GADA (56.1 RU), ICA (512 JDF units) and IA-2A (56.7 RU) in the first sample and remained positive for ICA (512 JDF units) and IA-2A (43.7 RU) in the second sample. Of the seven children, two $(28.6 \%)$ who initially tested positive for IAA turned IAAnegative. Both of them had high levels of ICA, GADA and IA-2A in their initial and in their follow-up sample. Out of the 104 initially antibody-negative control children one tested antibody-positive in the follow-up sample. This girl had an ICA level of 18 JDF units but remained negative for the other antibody specificities.

There was a positive correlation between ICA and IA-2A levels in subjects testing positive for both of these antibodies in their initial blood sample $(n=11)$ $\left(r_{s}=0.77, p=0.006\right)$ but not between the levels of ICA and GADA among subjects positive for both of these antibodies $(n=11)\left(r_{s}=0.36, p=0.29\right)$.

Autoantibodies and clinical characteristics. The children with IA-2A were younger than those with other antibodies ( $p=0.002$, data not shown) or the control children $(p=0.012$, Table 1$)$. Similarly, the children with multiple antibodies were younger than the subjects positive for one antibody only $(p=0.018$, data not shown) or the control children $(p=0.019$, Table 1). Relative body weight or waist:hip ratio did not differ between the control subjects and the subjects with any antibody (one or more), multiple antibodies (two or more) or those positive for any specific antibody.

Relation between first-phase insulin response, autoantibodies and HLA-DQB1 risk markers. The FPIRs did not differ significantly between the antibody positive subjects and control children (Fig. 2, Table 2). Similarly, the FPIRs did not differ significantly between the ICA-positive and control children (Fig. 2, Table 2), even if only those with an ICA level of 10 
Table 2. First-phase insulin response (FPIR) in relation to the initial antibody status in 206 healthy schoolchildren

\begin{tabular}{|c|c|c|c|c|c|c|}
\hline $\begin{array}{l}\text { Antibody positivity } \\
\text { in the initial blood sample }\end{array}$ & $n$ & $\begin{array}{l}\text { FPIR, mU/l } \\
\text { Median (IQR) }\end{array}$ & $\begin{array}{l}\text { FPIR } \\
<1^{\text {st }} \mathrm{ct} \\
n(\%)\end{array}$ & $\begin{array}{l}\text { FPIR } \\
<2.5^{\text {th }} \mathrm{ct} \\
n(\%)\end{array}$ & $\begin{array}{l}\text { FPIR } \\
<5^{\text {th }} \mathrm{ct} \\
n(\%)\end{array}$ & $\begin{array}{l}\text { FPIR } \\
<10^{\text {th }} \mathrm{ct} \\
n(\%)\end{array}$ \\
\hline Control subjects & 103 & $92(71-125)$ & & & & \\
\hline ICA-positive & 98 & $88(62-126)$ & $4(4.1)$ & $5(5.2)$ & $9(9.3)$ & $15(15.5)$ \\
\hline IA-2A-positive & 13 & $66^{a}(44-97)$ & $3(23.1)$ & $3(23.1)$ & $3(23.1)$ & $4(30.8)$ \\
\hline GADA-positive & 17 & $67^{\mathrm{b}}(57-101)$ & $3(17.6)$ & $3(17.6)$ & $3(17.6)$ & $3(17.6)$ \\
\hline
\end{tabular}

${ }^{\mathrm{a}} p=0.033,{ }^{\mathrm{b}} p=0.027,{ }^{\mathrm{c}} p=0.010$ and ${ }^{\mathrm{d}} p=0.048$, when compared with the control children. The centile values in control children are the following: $1^{\text {st }} \mathrm{ct}=29.5 \mathrm{mU} / 1,2.5^{\text {th }} \mathrm{ct}=35.0 \mathrm{mU} / 1,5^{\text {th }} \mathrm{ct}=45.0 \mathrm{mU} / \mathrm{l}$ and $10^{\text {th }} \mathrm{ct}=52.1 \mathrm{mU} / 1$

Table 3. Characteristics of the children with first-phase insulin response (FPIR) below the $1^{\text {st }}$ centile of the values in healthy control children

\begin{tabular}{|c|c|c|c|c|c|c|c|c|c|c|c|c|}
\hline $\begin{array}{l}\text { Subject } \\
\text { No. }\end{array}$ & $\begin{array}{l}\text { FPIR } \\
(\mathrm{mU} / \mathrm{l})\end{array}$ & Sex & $\begin{array}{l}\text { Age } \\
\text { (years) }\end{array}$ & $\begin{array}{l}D Q B 1 \\
\text { genotype }\end{array}$ & $\begin{array}{l}\text { 1. ICA } \\
\text { (JDF-U) }\end{array}$ & $\begin{array}{l}\text { 2. ICA } \\
\text { (JDF-U) }\end{array}$ & $\begin{array}{l}\text { 1. IA-2A } \\
(\mathrm{RU})\end{array}$ & $\begin{array}{l}\text { 2. IA-2A } \\
(\mathrm{RU})\end{array}$ & $\begin{array}{l}\text { 1. GADA } \\
\text { (RU) }\end{array}$ & $\begin{array}{l}\text { 2. GADA } \\
\text { (RU) }\end{array}$ & $\begin{array}{l}\text { 1. IAA } \\
\text { (RU) }\end{array}$ & $\begin{array}{l}\text { 2. IAA } \\
\text { (RU) }\end{array}$ \\
\hline 1 & 23.5 & Boy & 14.9 & $* 02 / * 0602$ & 6 & 10 & - & - & - & - & - & - \\
\hline $2^{\mathrm{a}}$ & 10.5 & Boy & 10.7 & $* 0301 / * 0603$ & 66 & 130 & 95.7 & 44.8 & - & 9.2 & 15.1 & 4.82 \\
\hline 4 & 20.5 & Girl & 14.6 & $\mathrm{x} / \mathrm{x}$ & - & - & - & - & 24.6 & 16.4 & - & - \\
\hline 5 & 23.3 & Boy & 9.6 & $\mathrm{x} / \mathrm{x}$ & 6 & 10 & - & - & - & - & - & - \\
\hline 6 & 15.7 & Boy & 11.5 & $\mathrm{x} / \mathrm{x}$ & - & - & 2.6 & 2.3 & 88.3 & 80.2 & - & - \\
\hline
\end{tabular}

Subject No. 7 is the antibody-negative control child representing the $1^{\text {st }}$ centile of the FPIR values in control children. In $H L A-D Q B 1$ genotypes " $\mathrm{x}$ " indicates an unrecognised allele or homozygosity for the marked allele. Age denotes the age at the time of FPIR. The levels of antibodies are shown in the

JDF units or more $[n=46$, median FPIR $81 \mathrm{mU} / \mathrm{l}$, interquartile range (IQR) 65-123 mU/l], those with 20 JDF units or more $(n=12$, median FPIR $70 \mathrm{mU} / \mathrm{l}$, IQR $39-114 \mathrm{mU} / \mathrm{l})$ or those with $40 \mathrm{JDF}$ units or more $(n=4$, median FPIR $71 \mathrm{mU} / 1$, IQR 24-111 mU/l) were compared with the control children. In contrast, the subjects with IA-2A, GADA, IAA or multiple antibodies in their initial blood sample had lower FPIRs than the control children (Mann-Whitney U test: $p=0.033, p=0.027, p=0.01$ and $p=0.048$, respectively) (Fig. 2, Table 2). The median FPIR in those 11 children with single antibody positivity to a biochemically characterised antigen, irrespective of ICA status, was $77 \mathrm{mU} / 1$ (IQR 58-109 mU/l) which was lower, although not significantly so $(p=0.158)$, than that seen in the control children (median $92 \mathrm{mU} / \mathrm{l}$, IQR 71-125 mU/I). No significant correlation between age and FPIR either among the antibody-positive children or among the control children was observed $\left(r_{s}=0.074\right.$ and 0.124 , respectively).

There were no significant differences in the FPIR between subjects with and without the DQB $1 * 02$, DQB $1 * 0302$, DQB $1 * 0301$ or DQB $1 * 0602-3$ allele nor between those with and without the DQB $1 * 02 /$ *0302, DQB1*0302/x or DQB1*02/x (" $\mathrm{x}$ " indicates initial (1.) and follow-up sample (2.). "_" indicates antibodynegative sample. ${ }^{\text {a }}$ Progressed to clinical diabetes at the age of 13.4 years. ${ }^{b}$ Progressed to clinical diabetes at the age of 12.2 years. JDF-U = Juvenile Diabetes Foundation units

unrecognised allele or homozygosity for a marked allele) genotype (data not shown). These results remained non-significant irrespective of whether the control subjects were or were not included in the analysis.

Altogether, six $(5.8 \%)$ initially antibody-positive subjects had a FPIR value below the 1st centile of the FPIR values seen in the control children ( $<29.5 \mathrm{mU} / \mathrm{l}$ ) (Fig. 2.). The characteristics of these children are shown in Table 3. Of these three tested positive for one antibody specificity and one for two antibodies in both samples. The two remaining subjects had three or four antibodies on both occasions. None of these six children had a $D Q B 1$ genotype associated with increased risk for progression to Type I diabetes, whereas three of them carried the DQB1*0602 or *0603 allele conferring decreased risk.

Progression to Type I diabetes. Two children have progressed to clinical diabetes (Table 3). The initial blood samples were taken 4.4 (patient No.2) and 3.1 years (patient No.3) before the diagnosis. Both subjects had three or four antibodies in their initial as well as in their follow-up sample. An IVGTT was done at the time of the second sample, 2.7 (patient No.2) and 1.4 (patient No.3) years before the diag- 
nosis. Both children who progressed to clinical diabetes had FPIR values under the 1 st centile $(10.5$ and $26.2 \mathrm{mU} / \mathrm{l}$ ). No chronic disorders were reported other than allergy to citrus fruits in the second subject. Both children had had a non-specific upper respiratory tract infection and the first subject also had acute otitis media between the two examinations. He carried the DQB1*0301/*0603 genotype whereas the second subject had the DQB1*02/ *0602 genotype (the DQA1*05-DQB1*02 haplotype).

\section{Discussion}

Data on aetiological factors and the course of the destruction of pancreatic beta cells are essential to resolve the pathomechanisms of Type I diabetes. Whether the autoimmune destructive process always leads to clinical disease and whether this process is similar in all people (e.g. in first-degree relatives and in the general population) is not known. Our study further explains the course of beta-cell autoimmunity in healthy children representing the general population and provides valuable data on the relations between humoral, genetic and metabolic markers in such subjects.

The natural course of humoral autoimmunity, i.e. changes in positivity and quantity of autoantibodies, has mainly been studied in first-degree relatives of patients with Type I diabetes [19-32]. These studies have shown fluctuations in the antibody levels and seroconversions from antibody positivity to antibody negativity and vice versa during the follow-up. In general, antibody positivity seems to be a rather stable phenomenon at least in older children because antibodies disappear only in a few subjects even during a long follow-up period [22, 28, 29]. Seroconversion to antibody negativity has been shown to be associated with low titre of antibodies and single antibody positivity [25, 29], whereas stable antibodies are more often associated with high titres and the presence of multiple antibodies [28, 29,31]. Whether these findings are also valid in the general population is not well documented for the various antibody specificities. The reported proportions of initially ICApositive subjects turning ICA-negative during follow-up among the general population have varied from $14 \%$ to $78 \%$ [33-37]. One group studied 2908 healthy schoolchildren and had follow-up samples from 55 initially ICA-positive subjects. Of these $17(31 \%)$ were ICA-negative in their second sample taken 7-14 months after the first sample and most of those who seroconverted had low initial levels of ICA [37]. One study has reported fluctuation in the titre and positivity of GADA in subjects with a negative family history for Type I diabetes [38] and seroconversion from IAA positivity to IAA negativity was reported in some French schoolchildren [28]. Results from our study confirm that all individual markers of humoral islet autoimmunity can fluctuate during prospective follow-up including those in healthy schoolchildren. In the majority of subjects, however, the antibody status remained stable and e.g. seroconversion to ICA negativity was relatively rare and usually associated with low titres and positivity for ICA only.

There is only scanty data on the relations between autoantibodies and demographic characteristics in people with signs of preclinical diabetes representing the general population. A higher frequency of GADA in non-diabetic schoolchildren over 10 years of age than in those under this age and a male predominance of these antibodies has been reported [39]. In the same study, IAA was associated with young age, whereas ICA and IA-2A did not vary with age or sex. Another study reported normal body mass indexes in 40 ICA-positive healthy schoolchildren [35]. In our series of unaffected schoolchildren, we could not find any relation between clinical characteristics and the presence of autoantibodies, with the exception of an association between young age and IA-2A and multiple antibodies.

Several studies have reported decreased FPIR to intravenous glucose in ICA-positive, first-degree relatives of patients with Type I diabetes [40, 41]. Recently, a strong correlation between the presence of GADA and low FPIR was reported [42]. In that study, there were also 13 subjects with multiple antibodies in the initial screening without signs of impaired beta-cell function. Only a limited number of studies have been published reporting relations between autoantibodies and FPIR in the general population. In a study of 40 ICA-positive schoolchildren 2 subjects had a low FPIR [35]. These subjects had high titres of ICA and also tested positive for GADA and IAA. In addition, one subject was initially positive for complement-fixing ICA and GADA and FPIR decreased under the 1st centile after 6 months of follow-up. In a recent German study, $60 \%(10 / 17)$ of schoolchildren with multiple antibodies were reported to have a decreased FPIR after 4-16 months of follow-up [43]. In our study a reduced FPIR was observed in children with IA-2A, GADA, IAA, or multiple antibodies. There was, however, a substantial overlapping of children between the groups testing positive for IA-2A, GADA or IAA and those with multiple antibodies. This indicates that a decreased FPIR is primarily associated with positivity for multiple antibodies, although the IAApositive children among those with multiple antibodies had the lowest FPIR median. Our observation confirms that humoral autoimmunity against betacell antigens reflects impaired beta-cell function and probably an ongoing destruction of the insulin-producing cells. 
Genetic determinants of FPIR are poorly defined. One study has reported a reduced insulin response to i.v. glucose in $H L A$-identical siblings of patients with Type I diabetes [44] whereas another study failed to show any relation between the degree of $H L A$ identity or $H L A$ class II antigens and the early insulin response [45]. We have previously reported an association between a reduced FPIR and HLArisk markers in siblings of children with Type I diabetes [46]. In the present study on healthy schoolchildren, we did not, however, observe any relation between $H L A-D Q B 1$-risk alleles or genotypes and FPIR, irrespective of the antibody status. These observations could reflect differences in the genetic background or in the disease process itself between siblings of children with Type I diabetes and healthy non-selected schoolchildren. Family members could carry additional susceptibility genes which have an epistatic effect with HLA genes on the disease process and therefore decreased FPIRs are found to be associated with HLA markers among siblings, but not necessarily in the general population.

Neither of the two children who progressed to clinical diabetes in our study had an HLA-DQB1 genotype shown to be associated with increased risk for Type I diabetes nor the DQB1*0302 allele conferring the strongest disease susceptibility. In contrast, both of them carried the DQB $1 * 0602$ or *0603 allele that has been observed to be associated with a decreased susceptibility for Type I diabetes. Thus, these two children would not have been identified on the basis of $H L A-D Q B 1$-risk markers but should have been classified as subjects with a decreased genetic risk. In contrast, on the basis of humoral or metabolic markers or both they would have been identified correctly as high-risk subjects.

Both earlier studies and the distribution of $H L A$ alleles in the previously diagnosed children in the present study region show HLA-DQB1*0302 and DQB1*02 to be the strongest susceptibility alleles for Type I diabetes among Finnish children [16, 47]. Thus the lack of any apparent association between these genetic risk markers and FPIR or progression to overt diabetes in the present series is unexpected. The number of children with a reduced FPIR and of those who presented with clinical disease is, however, low which limits the interpretation of the data. On the other hand, we have previously observed a higher frequency of protective $D Q B 1$ alleles among children diagnosed with Type I diabetes at an age older than 5 years than in those diagnosed at a younger age [48]. This might contribute to the present results because all schoolchildren were older than 9 years when tested for their FPIR or diagnosed with Type I diabetes.

We show that the presence of autoantibodies against specific beta-cell antigens is usually a stable phenomenon in unaffected schoolchildren, particu- larly in those with multiple antibodies, although any of these markers can occasionally disappear during follow-up. We also observed that a reduced early insulin response was related to autoantibodies but not to the $H L A-D Q B 1$-risk markers in this series of non-diabetic children over the age of 9 years. Our observations suggest in addition that the $D Q B 1$ alleles conferring decreased disease susceptibility do not provide protection from strong humoral beta-cell autoimmunity, deterioration of the beta-cell function or from progression to overt Type I diabetes in initially unaffected schoolchildren representing the general population.

Acknowledgements. We thank S. Anttila, S. Heikkilä, A. Jaakkola, P. Koramo, T. Laurén, R. Päkkilä and R. Suominen for their skilful technical assistance.

This work was supported by grants from the Alma och K. A. Snellman Foundation (Oulu, Finland), the Finnish Diabetes Research Foundation, the Foundation for Paediatric Research (Helsinki, Finland), Finska Läkaresällskapet (Helsinki, Finland), the Novo Nordisk Foundation and the Medical Research Council, Academy of Finland.

\section{References}

1. Dahlquist G, Blom I, Holmgren G et al. (1985) The epidemiology of diabetes in Swedish children 0-14 years: a six-year prospective study. Diabetologia 28: 802-808

2. Tuomilehto J, Lounamaa R, Tuomilehto-Wolf E et al. (1992) Epidemiology of childhood diabetes in Finland: background of a nationwide study of Type I (insulin-dependent) diabetes mellitus. Diabetologia 35: 70-76

3. Kulmala P, Savola K, Petersen JS et al. (1998) Prediction of insulin-dependent diabetes mellitus in siblings of children with diabetes - a population based study. J Clin Invest 101: 327-336

4. Bingley PJ, the ICARUS Group (1996) Interactions of age, islet cell antibodies, insulin autoantibodies, and first-phase insulin response in predicting risk of progression to IDDM in $\mathrm{ICA}^{+}$relatives. Diabetes 45: 1720-1728

5. Sorva R, Perheentupa J, Tolppanen EM (1984) A novel format for a growth chart. Acta Paed Scand 73: 527-529

6. Bingley PJ, Colman P, Eisenbarth GS et al. (1992) Standardization of IVGTT to predict IDDM. Diabetes Care 15: 1313-1316

7. Andersen L, Dinesen B, Jørgensen PN et al. (1993) Enzyme immunoassay for intact human insulin in serum or plasma. Clin Chem 39: 578-582

8. Hjelm M (1969) Enzymatic determination of hexoses in blood and urine. Scand J Clin Lab Invest 192[Suppl]:85-98

9. Bottazzo GF, Florin-Christensen A, Doniach D (1974) Isletcell antibodies in diabetes mellitus with autoimmune polyendocrine deficiencies. Lancet ii:1279-1282

10. Greenbaum CJ, Palmer JP, Nagataki S et al. (1992) Improved specificity of ICA assays in the fourth international immunology of diabetes serum exchange workshop. Diabetes 41: 1570-1574

11. Savola K, Bonifacio E, Sabbah E et al. (1998) IA-2 antibodies - a sensitive marker of IDDM with clinical onset in children and adolescents. Diabetologia 41: 424-429

12. Verge CF, Stenger D, Bonifacio E et al. (1998) Combined use of autoantibodies (IA-2ab, GADab, IAA, ICA) in type I diabetes: combinatorial islet autoantibody workshop. Diabetes 47: 1857-1866 
13. Sabbah E, Kulmala P, Veijola R et al. (1996) $\mathrm{GAD}_{65}$ antibodies in relation to other antibodies and genetic risk markers in children with newly diagnosed IDDM. J Clin Endocrinol Metab 81: 2455-2459

14. Williams AJ, Bingley PJ, Bonifacio E, Palmer JP, Gale EA (1997) A novel micro-assay for insulin autoantibodies. J Autoimmun 10: 473-478

15. Sjöroos M, Iitiä A, Ilonen J, Reijonen H, Lövgren T (1995) Triple-label hybridization assay for type-1 diabetes-related HLA alleles. Biotechniques 18: 870-877

16. Ilonen J, Reijonen H, Herva E et al. (1996) Rapid HLADQB1 genotyping for four alleles in the assessment of risk for IDDM in the Finnish population. Diabetes Care 19: 795-800

17. Sjöroos M, Ilonen J, Reijonen H, Lövgren T (1998) Time-resolved fluorometry based sandwich hybridisation assay for HLA-DQA1 typing. Disease Markers 14: 9-19

18. Schuster J (1988) EXACTB and CONF: exact unconditional procedures for binominal data. American Statistician 42: 234

19. Spencer KM, Tarn A, Dean BM, Lister J, Bottazzo GF (1984) Fluctuating islet cell autoimmunity in unaffected relatives of patients with insulin dependent diabetes. Lancet i:746-766

20. Johnston C, Millward BA, Hoskins P, Leslie RD, Bottazzo GF, Pyke DA (1989) Islet-cell antibodies as predictors of the later development of Type I (insulin-dependent) diabetes. A study in identical twins. Diabetologia 32: 382-386

21. Krischer JP, Schatz D, Riley WJ et al. (1993) Insulin and islet cell autoantibodies as time-dependent covariates in the development of insulin-dependent diabetes: a prospective study in relatives. J Clin Endocrinol Metab 77: 743-749

22. Bingley PJ, Christie MR, Bonifacio E et al. (1994) Combined analysis of autoantibodies improves prediction of IDDM in islet cell autoantibody-positive relatives. Diabetes 43: 1304-1310

23. Gorus FK, Vandewalle CL, Dorchy H et al. (1994) Influence of age on the associations among insulin autoantibodies, islet cell antibodies, and HLA DQA1*0301-DQB1*0301 in siblings of patients with type 1 (insulin-dependent) diabetes mellitus. J Clin Endocrinol Metab 78: 1172-1178

24. Knip M, Vähäsalo P, Karjalainen J, Lounamaa R, Åkerblom HK, the Childhood Diabetes in Finland Study Group (1994) Natural history of preclinical IDDM in high risk siblings. Diabetologia 37: 388-393

25. Roll U, Christie MR, Eberhard S, Ziegler A-G (1994) Associations of anti-GAD antibodies with islet cell antibodies in first-degree relatives of type 1 diabetic patients. Diabetes 43: 154-160

26. Schmidli RS, DeAizpurua HJ, Harrison LC, Colman PG (1994) Antibodies to glutamic acid decarboxylase in at-risk and clinical insulin-dependent diabetic subjects: relationship to age, sex and islet cell antibody status, and temporal profile. J Autoimmun 7: 55-66

27. Schott M, Schatz D, Atkinson MA et al. (1994) GAD65 autoantibodies increase the predictability but not the sensitivity of islet cell and insulin autoantibodies for developing insulin dependent diabetes mellitus. J Autoimmun 7: 865-872

28. Lévy-Marchal C, Dubois F, Noël M, Tichet J, Czernichow P (1995) Immunogenetic determinants and prediction of IDDM in French schoolchildren. Diabetes 44: 1029-1032

29. Roll U, Christie MR, Füchtenbusch M, Payton MA, Hawkes CJ, Ziegler AG (1996) Perinatal autoimmunity in offspring of diabetic parents. The German multicenter BABY-DIAB study: detection of humoral immune responses to islet antigens in early childhood. Diabetes 45: 967-973

30. Yu L, Rewers M, Gianani R (1996) Antiislet autoantibodies usually develop sequentially rather than simultaneously. J Clin Endocrinol Metab 81: 4264-4267

31. Christie MR, Roll U, Payton MA, Hatfield EC, Ziegler AG (1997) Validity of screening for individuals at risk for type I diabetes by combined analysis of antibodies to recombinant proteins. Diabetes Care 20: 965-970

32. Hawa M, Rowe R, Lan MS et al. (1997) Value of antibodies to islet protein tyrosine phosphatase-like molecule in predicting type 1 diabetes. Diabetes 46: 1270-1275

33. Landin-Olsson M, Karlsson A, Dahlquist G, Blom L, Lernmark $\AA$, Sundquist G (1989) Islet cell and other organ-specific autoantibodies in all children developing Type I (insulindependent) diabetes mellitus in Sweden during one year and in matched control children. Diabetologia 32: 387-395

34. Boehm BO, Seissler J, Glück M et al. (1991) The level and the persistence of islet cell antibodies in healthy schoolchildren are associated with polymorphic residues of the HLADQ $\beta$ chain. Dis Markers 9: 273-280

35. Seissler J, Hering B, Richter W et al. (1992) Antibodies to the $\mathrm{Mr} 64,000(64 \mathrm{~K})$ protein in islet cell antibody positive non-diabetic individuals indicate high risk for impaired beta-cell function. Diabetologia 35: 550-554

36. Lévy-Marchal C, Tichet J, Fajardy I, Gu XF, Dubois F, Czernichow P (1992) Islet cell antibodies in normal French schoolchildren. Diabetologia 35: 577-582

37. Bingley PJ, Bonifacio E, Shattock M et al. (1993) Can islet cell antibodies predict IDDM in the general population? Diabetes Care 16: 45-50

38. Aanstoot HJ, Sigurdsson E, Jaffe M et al. (1994) Value of antibodies to $\mathrm{GAD}_{65}$ combined with islet cell cytoplasmic antibodies for predicting IDDM in a childhood population. Diabetologia 37: 917-924

39. Bingley PJ, Bonifacio E, Williams AJ, Genovese S, Bottazzo GF, Gale EA (1997) Prediction of IDDM in the general population. Strategies based on combinations of autoantibody markers. Diabetes 46: 1701-1710

40. Robert JJ, Deschamps I, Chevenne D, Roger M, Mogenet A, Boitard C (1991) Relationship between first-phase insulin secretion and age, HLA, islet cell antibody status, and development of type 1 diabetes in 220 juvenile first-degree relatives of diabetic patients. Diabetes Care 14: 718-723

41. Verge CF, Gianani R, Kawasaki E et al. (1996) Prediction of type 1 diabetes in first-degree relatives using a combination of insulin, GAD, and ICA512bdc/Ia-2 autoantibodies. Diabetes 45: 926-933

42. Greenbaum CJ, Sears KL, Kahn SE, Palmer JP (1999) Relationship of $\beta$-cell function and autoantibodies to progression and nonprogression of subclinical type 1 diabetes. Follow-up of the Seattle Family Study. Diabetes 48: 170-175

43. Strebelow M, Schlosser M, Ziegler B, Rjasanowski I, Ziegler M (1999) Karlsburg Type I diabetes risk study of a general population: frequencies and interactions of the four major Type I diabetes-associated autoantibodies studied in 9419 schoolchildren. Diabetologia 42: 661-670

44. Raghu P, Johnston C, Beard JC, Bergman R, McCulloch DK, Palmer JP (1985) Reduced insulin sensitivity in non-diabetic, HLA-identical siblings of insulin-dependent diabetic subjects. Diabetes 34: 991-994

45. Lindgren F, Dahlquist G, Efendic S et al. (1987) Glucose-induced insulin response and insulin sensitivity is not related to HLA-type but to age in young siblings of Type I (insulindependent) diabetic patients. Diabetologia 30: 727-732

46. Veijola R, Vähäsalo P, Tuomilehto-Wolf E et al. (1995) Human leukocyte antigen identity and DQ risk alleles in autoantibody-positive siblings of children with IDDM are associated with reduced early insulin response. Diabetes 44: 1021-1028

47. Reijonen H, Ilonen J, Knip M, Åkerblom HK (1981) HLADQB1 alleles and absence of Asp57 susceptibility factors of IDDM in Finland. Diabetes 40: 1640-1644

48. Komulainen J, Kulmala P, Savola K et al. (1999) Clinical, autoimmune and genetic characteristics of very young children with type 1 diabetes. Diabetes Care 22: 1950-1955 